ACTA MYCOLOGICA

Vol. 29 (1): $95-98$

1994

\title{
New localities of some rare species of Uredinales in Poland
}

\section{AGATA WOECZAŃSKA}

Maria Curie-Skłodowska University, Institute of Biology, Department of Botany, Akademicka 19.

20-033 Lublin, Poland

W ol c z a ń s k a $\Lambda$. New localities of some rare species of Uredinales in Poland. Acta Mycol. 29 (1): 95-98. 1994.

The paper presents new localities of some rare species of Uredinales, They were collected in south-eastern part of Poland.

Since 1990 investigations on the occurrence of microscope fitopathogenic fungi have been undertaken in Doly Jasielsko-Sanockie and in Beskid Niski mountains. A great many herbarium specimens have been collected, which are now being identified and which will be gradually published.

Among the collected rust fungi, the most interesting species identified were, as follows: Puccinia cnici-oleracei on Cirsium oleraceum, P. dentariae on Cardamine bulbifera, $P$, deschampsiae on Deschampsia caespitosa, $P$. vulpinae on Carex vulpina, Pucciniastrum guttatum on Galium mollugo, Uromyces ononidis on Ononis arvensis. These species are known to occur only in few localities. Puccinia cariciola found on Carex supina and collected in Wyżyna Małopolska has been included in the index.

The data regarding the occurrence of the fungi have been based on available literature (D a n il k i e w i c z, 1985, 1987; M a jew s k i, 1977, 1979; M u renk o, 1988; Romaszewska-S a lata, 1982; R omaszewska-S a tata, Mutenk o, 1983).

\section{COLLECTED SPECIES AND THEIR LOCALITIES}

Puccinia caricicola Fuck. on Carex supina Willd. ex Wahlenb.: Podgrodzie near Ćmielów, on a steppe slope (leg. et det. J. R o m a s z e w s k a - S a ł a t a): VIII. The fungus has been recorded so far in Poland only in Góry Pieprzowe mountains near Sandomierz (Fig. 1 A). 
Only Uredinia can be found on the attacked specimens. Subsequently urediniospores of the size 17-30 $\times 14-20 \mu \mathrm{m}$ develop and few amfispores (Pl. 1. fot. $4 \mathrm{a}, \mathrm{b}$ ).
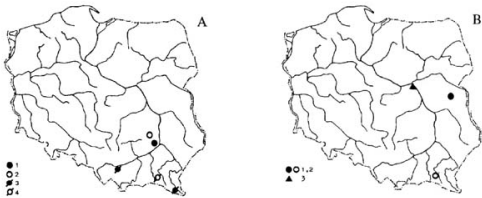

Fig. 1. A - The occurtence of Puccinis caricicola Fuck. on Carex supina (1, 2) and Puccinia dentariac (Alb. et Schw.) Fuck. on Cardamine buibifera $(3,4)$ 1.3-firsl localities: 2.4 - new localitics

B - The occurrence of Uromyces onoaidis Pass,

1, 2-cn Onosis arveasis; 3 - on Ononis spinosa

Puccinia cnici-oleracei Pers. ex Desm. on Cirsium oleraceum (L.) Scop.: Rymanow a side of a drainage ditch; VIII. The fungus on the host has so far been reported from: Beech Forest near Szczecin, Skonał Lake near Giżycko, Reserve Czartowe Pole (Rozlocze) and Ustrzyki Gơrne.

Puccinia dentariae (Alb. et Schw.) Fuck. on Cardamine bulbifera (L.) Crantz: Iwonicz. Zdroj, the slope of Gora Krzemionki (= Przedziwna), in Dentario glandulosae-Fagetum; V. The fungus has been noted only in Kalwaria Zebrzydowska and in Połonina Caryíska (Bieszczady) (Fig. 1 A).

The collected specimens are strongly attacked and deformed. Telia form very big clusters (up to $8 \mathrm{~cm}$ long), mainly on the stem and leaf petioles, and smaller ones on the leaves (Pl. 1, fot. 1 a, b). Teliospores are a bit larger than those described in literature and are respectively: $32-51$ x 14-18 $\mu \mathrm{m}$ (Pl. 1, fot. 2).

Puccinia deschampsiae Arth. on Deschampsia caespitosa (L.) Beauv.: Rymanów, in a meadow association belonging to the class Molinio-Arrhenatheretea; X. Other localitics: the surroundings of Szczecin and Stargard, Puszcza Kampinoska Forest, Mała Wieś n. Grójec, Babia Góra, Pieniny mountains, Bieszczady Zachodnie mountains, Woskrzenice (the valley of the River Krzna), Woroblin (the valley of the middle part of the River Bug) and Łeczna-Wlodawa Lake District. Only telia were found on the collected leaves. Teliospores are slightly larger than those described in literature and are respectively: $35-58 \times 14-20 \mu \mathrm{m}$ (Pl. 1, fot. 5). 

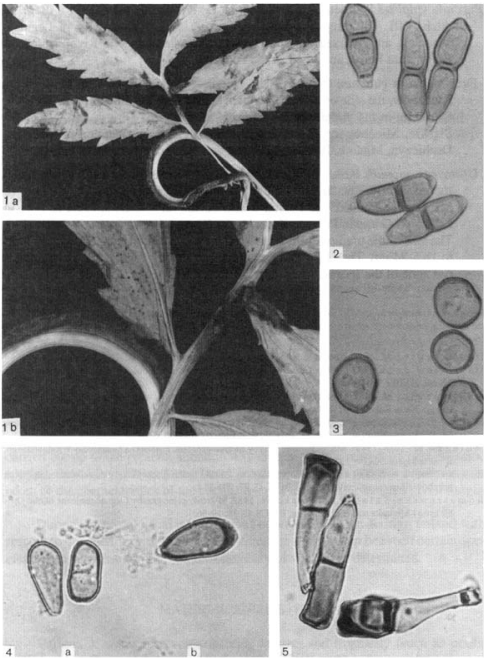

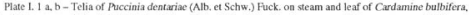
2 - Telsospores of Pucciaia dentarine (Alb, et Schw.) Fuck, 3 - Urediniospores of Unomyces ononidis Pass, on Ononis avensis, 4-Spores of Pucciaia caricicola Fuck, on Carex sapina a -urediniospores, b-an amfispore. 5 - Teliospores of Puccinia deschampsiac Arth. on Descharupsia caespitosa 
Puccinia vulpinae Schroet. on Carex vulpina L.: Rymanów, the side of a drainage ditch; VIII. The fungus has also been noted in the surroundings of Legnica, Wroclaw and Warszawa, Ludwikowo, Samostrzel by the River Noteć, in Białowieża Forest and Międzyrzec Podlaski.

Pucciniastrum guttatum (Schroet.) Hyl. Jørst. et Nannf. on Galium mollugo L.: Rymanów, the side of a drainage ditch; VIII. Other localities: Beech Forest $\mathrm{n}$. Szczecin, in the vicinity of Wroclaw, Warszawa and Olsztyn, in Ząbkowice Śląskic, Micchowice, Zakopane, Pieniny mountains, Kamień n. Mrągów, Drohiczyn, Mielnik, Białowieźa Forest and Puszcza Knyszyńska Forest.

Uromyces ononidis Pass, on Ononis arvensis L.: Rymanów, in Molinio-Arrhenatheretea; VIII. The fungus on this host has been recorded in the vicinity of Miẹdzyrzec Podlaski. In Poland it also occurs on Ononis spinosa L. only in Łomianki Górne in Puszcza Kampinoska Forest (Fig. 1 B).

The size of the urediniospores on the collected specimens ranged from 19.5-26 to $18.5-24 \mu \mathrm{m}$. They have 3-4 germ pores arranged irregulary or at an equatorial zone of the spores, covered by distinct, flattish cups (PI. I, 3).

\section{REFERENCES}

Dan il kie wi cz M., 1985. Notatki mikologiczne z doliny Krzny. Acta Mycol. XXI (1): 77-80.

D an il ki ewicz M. 1987 (1990). Grzyby pasozytnicze lewobrzeznej doliny srodkowego Bugu. Acta Mycol. XXIII : 37-80.

D a i i k i e w i cz M. 1987. Mikroskopowe grzyby pasozytnicze ląk i past wisk doliny Krzny. Zesz. Problem. Postęp. Nauk Rol. 307: 91-104.

Maje w ski T., 1977. Podstawczaki (Basidiomycetes), ruzawnikowe (Uredizales) I. [In:] Hora Polska, Grzyby. IX. Warszawa-Krak6́w. pp. 394, pl. I-III. - 1979. Ditto. II. Ibid. XI. pp. 426, pl. I-II.

Mu e n ko W, 1988 (1989). Mikroskopowe grzyby fitopatogeniczae Pojezierza Łpczyńsko-Whodawskiego. II. Acta Mycol. XXIV: 125-171.

R om a 82 e w s k a - S a l a t a J, 1982. Nowe dla flory Polski i rzadzicj spotykane gatunki mikroskopijnych grzybow fitopatogeniczaych. Ana. UMCS, C, 37: 201-214.

Romaszewska-S a lat a J., Mu e nko W., 1983. Mikroskopijne grzyby fitopatogeniczne okolic Drohiczyna i Mielnika nad Bugiem. Ann. UMCS, C, 38: 19-36. 